\title{
Toward a comprehensive taxonomic revision of the "hirculus" group of American Onthophagus Latreille, 1802 (Coleoptera, Scarabaeidae, Scarabaeinae)
}

\author{
Michele ROSSINI ${ }^{1, *}$, Fernando Z. VAZ-DE-MELLO ${ }^{2} \&$ Mario ZUNINO $^{3}$ \\ ${ }^{1}$ Università degli Studi di Urbino Carlo Bo, Dipartimento di Scienze Biomolecolari (DISB), \\ via A. Saffi 2, 61029, Urbino (PU), Italy. \\ ${ }^{2}$ Universidade Federal de Mato Grosso, Instituto de Biociências, Departamento de Biologia e \\ Zoologia, Av. Fernando Corrêa da Costa, 2367, Boa Esperança, 78060-900 - Cuiabá, MT, Brazil. \\ ${ }^{3}$ Independent researcher, Scuola di Biodiversità - Polo universitario Asti Studi Superiori. \\ Private: via G. Rossini, 9, 14100 Asti, Italy. \\ ${ }^{*}$ Corresponding author: micros.naturae@gmail.com \\ ${ }^{2}$ Email: vazdemello@gmail.com \\ ${ }^{3}$ Email: mariozunino@hotmail.it \\ ${ }^{1}$ urn:1sid:zoobank.org:author:2698881E-C265-42DB-8A8E-0BE3A5BDDB97
${ }^{2}$ urn:1sid:zoobank.org:author:2FF2B7D6-1A6B-43C1-9966-A1A949FB2B05
${ }^{3}$ urn:1sid:zoobank.org:author:A1EE6CAE-8FC5-413B-9984-625DF6C4C486
}

\begin{abstract}
The taxonomy of the American Onthophagus Latreille, 1802 included in the "hirculus" group is revised, and a study of their morphology allows for the delineation of five species-complexes. Herein, we provide a diagnosis of the "hirculus" group, an illustrated key to the complexes, along with a descriptive overview of their taxonomy and geographic distribution. Onthophagus hirculus Mannerheim, 1829 is considered to be a junior synonym of $O$. hircus Billberg, 1815, which is here demonstrated to be a valid species name. Thus, the "hirculus" group is here renamed the "hircus" group. Furthermore, a general scheme of the genital organs of American Onthophagus is provided, including names of different anatomical parts and a brief discussion on the need for nomenclatural stability for the genitalia of scarab beetles.
\end{abstract}

Keywords. Dung beetles, America, new synonym, Billberg, species-complex.

Rossini M., Vaz-de-Mello F.Z. \& Zunino M. 2018. Toward a comprehensive taxonomic revision of the "hirculus" group of American Onthophagus Latreille, 1802 (Coleoptera, Scarabaeidae, Scarabaeinae). European Journal of Taxonomy 432: 1-21. https://doi.org/10.5852/ejt.2018.432

\section{Introduction}

With ca 2200 species described (Schoolmeesters 2016), Onthophagus Latreille, 1802 is a hyperdiverse genus within the subfamily Scarabaeinae Latreille, 1802 and represents more than $38 \%$ of the known Scarabaeinae dung beetles. Scarabaeinae provide major ecological services to ecosystems (Nichols et al. 
2008), and are considered important biological indicators because they are highly sensitive to changing environmental conditions. Furthermore, the great variety of morphological shapes exhibited by dung beetles (e.g., cephalic and pronotal horns) has been a recent focus of evolutionary and developmental biology studies (e.g., Emlen et al. 2005; Moczek 2011; Tarasov \& Génier 2015; see also Zunino \& Halffter 2007 and literature therein).

Onthophagus is a widely distributed genus that includes small to large-sized species and exhibits its highest diversity in the Afrotropical and Oriental regions. In contrast, the American and Australian continents harbour a significantly lower number of native species, respectively about 170 according to Pulido-Herrera \& Zunino (2007) and 200 according to Matthews (1972) and subsequent authors (e.g., Storey \& Weir 1990; Monteith \& Storey 2013). While the comprehensive taxonomic revisions of Australian Onthophagus make this estimation acceptable for the continent, the poor diversity of the genus in the New World seems to be fairly questionable, as over the last 50 years the study of the genus has been mainly focused either on restricted geographic regions (e.g., Howden \& Cartwright 1963; Howden \& Young 1981; Kohlmann \& Solís 2001) or species groups (e.g., Zunino \& Halffter 1988). Nonetheless, over the last two decades, scattered descriptions of several new species, mainly from the Mexican Transition Zone and Central America, have been published (e.g., Génier \& Howden 1999; Delgado \& Curoe 2014; Génier \& Howden 2014; Moctezuma et al. 2016).

Boucomont (1932) separated the then-known American Onthophagus into 13 diagnostic groups, providing identification keys and notes on the type specimens of the most common species from the USA, Mexico, Central and South America. This classification was considered to be largely artificial, and most of the species were subsequently rearranged in different groups, with hypotheses of phylogenetic relationships and delineation of new species-groups (Zunino \& Halffter 1988; Howden \& Gill 1993; Zunino \& Halffter 1997; Kohlmann \& Solís 2001). Zunino \& Halffter (1997) recognized five of the eight species-groups currently identified within the American Onthophagus, and the hirculus group was considered to be the most species-rich ( 26 species) and widely distributed across the New World.

In this paper, we provide preliminary results of a taxonomic revision of the hirculus group, which represent a fundamental starting point for an in-depth taxonomic and phylogenetic study of the complexes identified within the group.

\section{Material and methods}

The morphology-based study was carried out primarily on the type specimens of all the named species originally included in the hirculus group. The morphology of these individuals was used as a reference for the correct identification of a large sample of specimens housed in European and American natural history collections. This stage of the research was fundamental to have well-identified specimens at hand, in order to gather proper geographical data and identify new species to be included in the hirculus group. Specimens deposited in the following public and private collections have been analysed:

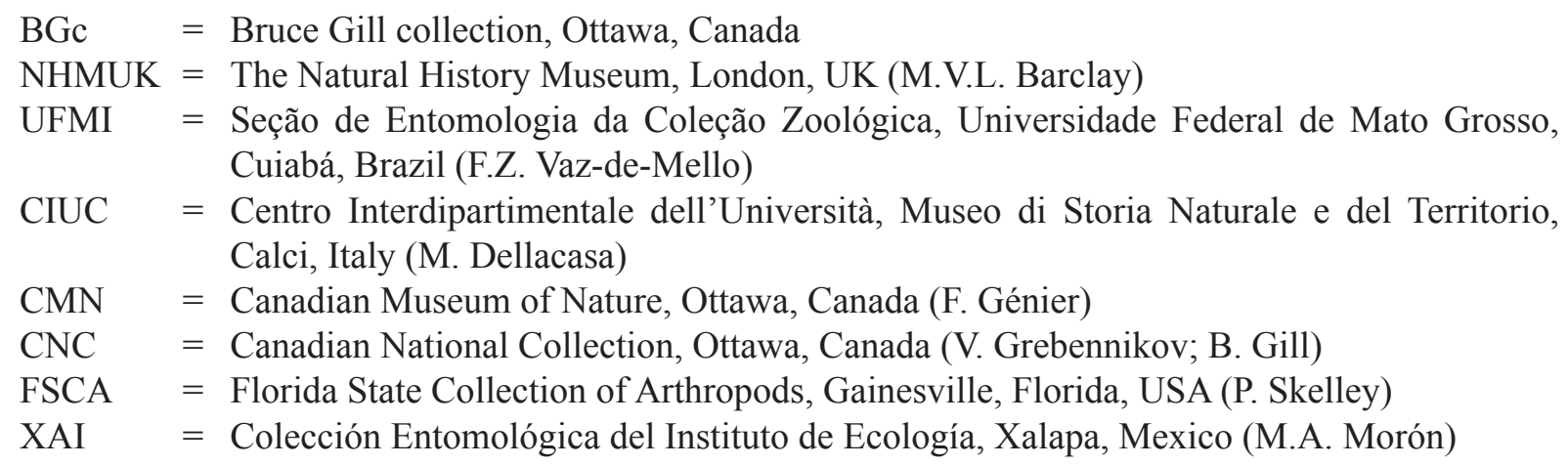




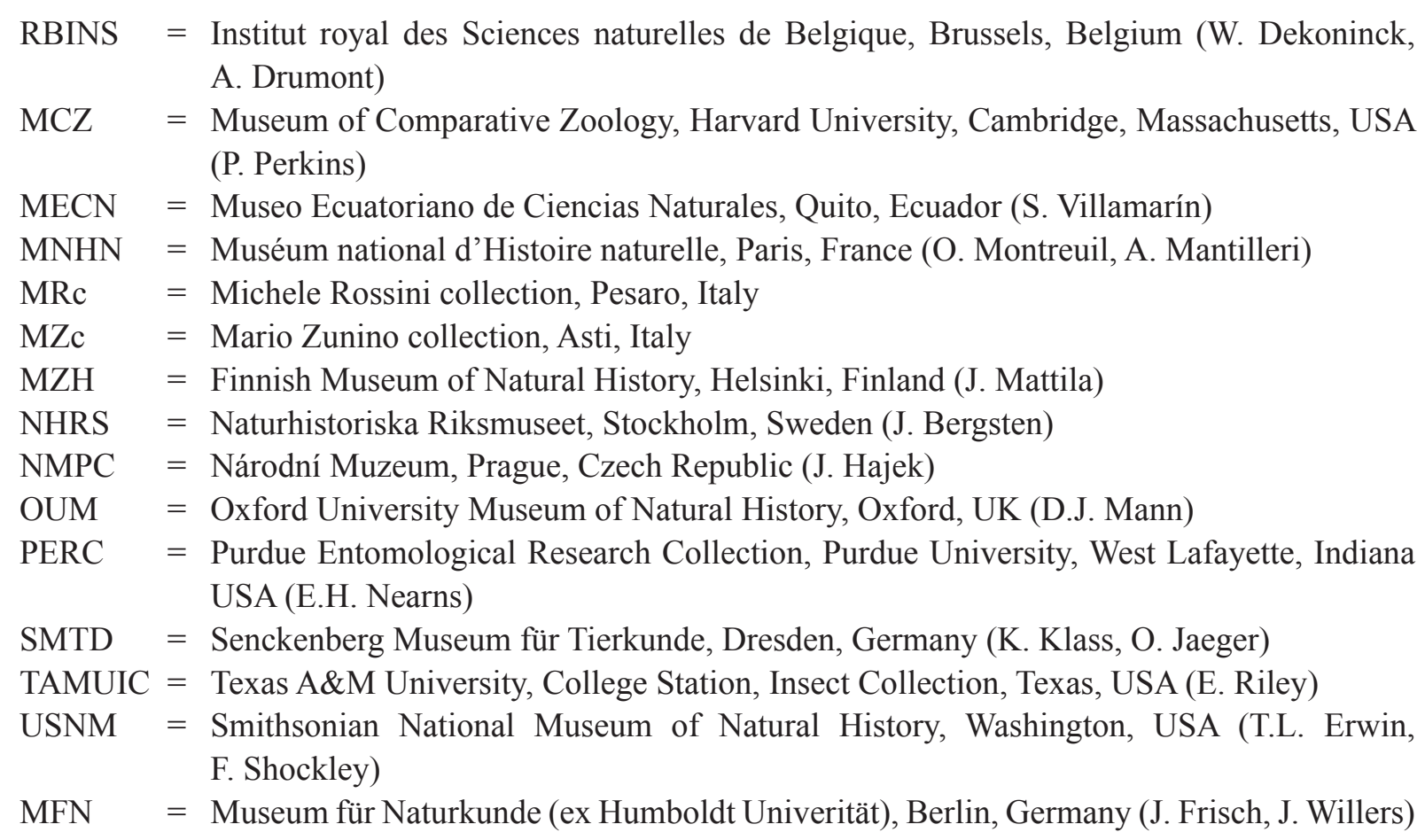

External morphology and genital organs of the beetles have been thoroughly examined. For the study of the genitalia, specimens were rehydrated in hot water and dissected parts were cleared in a $10 \%$ $\mathrm{KOH}$ solution for 10-15 minutes. Aedeagi were glued onto cardboard, while endophallic lamellae were mounted on the same cardboard with DMHF resin for examination and photography. Female genitalia were preserved in microvials with glycerol and pinned with the specimens. Morphological analyses were conducted using a Leica MZ75 stereo microscope, while pictures of the body parts were taken with a Canon 550D EOS camera, either with a Canon MP-E $65 \mathrm{~mm} \mathrm{f} / 2.8$ Macro lens or a Promicron adapter attached to the stereo microscope. Illustrations were enhanced with Adobe Photoshop and Illustrator CC 2015 for Mac. A distribution map was created with QGIS (2017, v. 2.18.2).

In order to avoid any misunderstanding concerning the genital structures examined and used in the following papers, we provide a general scheme of the genitalia of both sexes. For the paramere parts we used the nomenclature proposed by Krikken \& Huijbregts (2009), while the terminology adopted for the endophallic lamellae and female genitalia follows Zunino \& Halffter (1988) and Tarasov \& Solodovnikov (2011) (Fig. 1 and captions).

As already pointed out by one of us (Zunino 2014 and literature cited therein), the lack of a stable nomenclatural system to be applied to the genital organs of scarab beetles led many authors to introduce a large deal of ambiguity into the literature. On exploring the phylogeny of the Onthophagini, Tarasov \& Solodovnikov (2011) provided new names for the endophallic pieces that form the accessory lamellae (as originally named by Binaghi et al. 1969), using the term 'sclerite'. However, we consider the usage of 'lamella' to be more appropriate for reference to any secondarily sclerotized piece of the internal sac (except for the raspulae, spiculae and spiny lamellar belt), as 'sclerite' in entomology correctly refers to parts of segments of the exoskeleton of the insect - somites - such as sternites, tergites, pleurites, etc. and their appendages (Snodgrass 1935; Torre-Bueno 1937).

Original labels of the type specimens examined are quoted between square brackets and separated by a comma. 

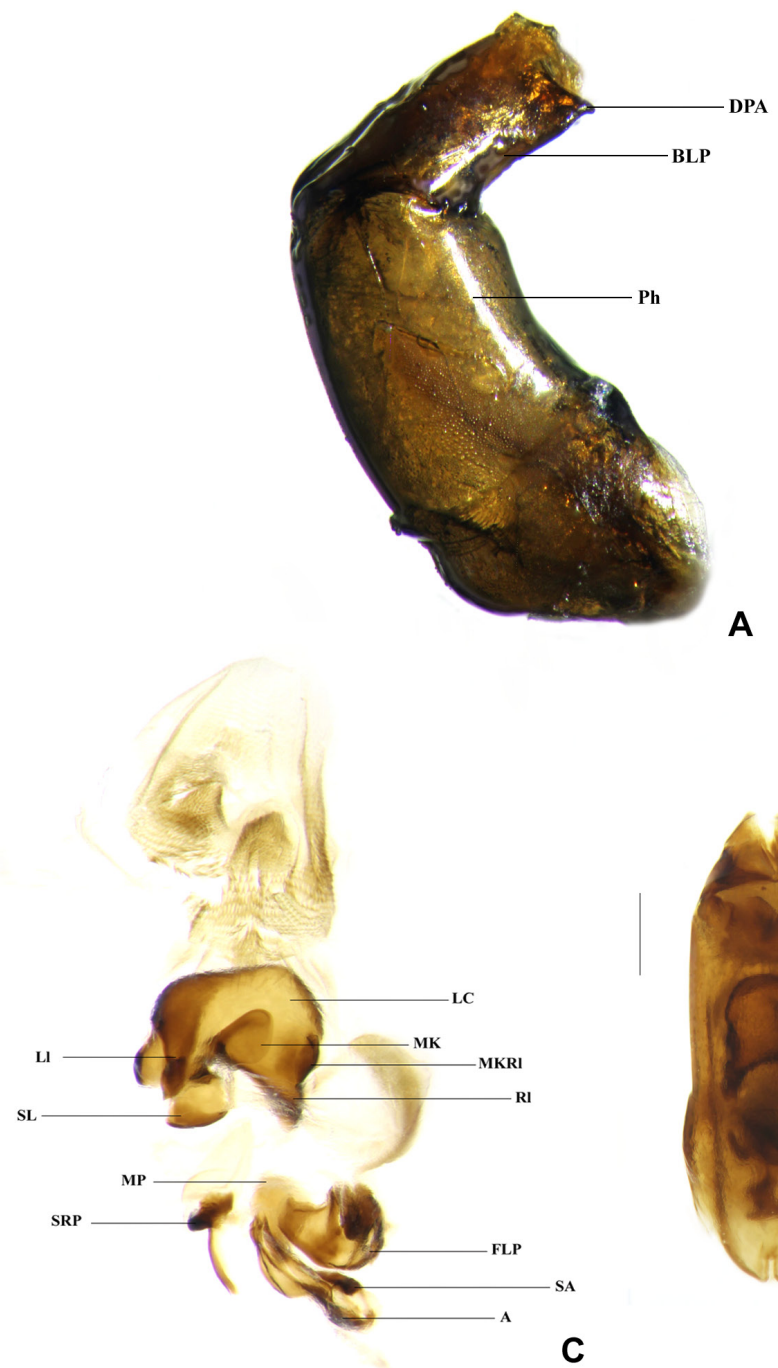

C

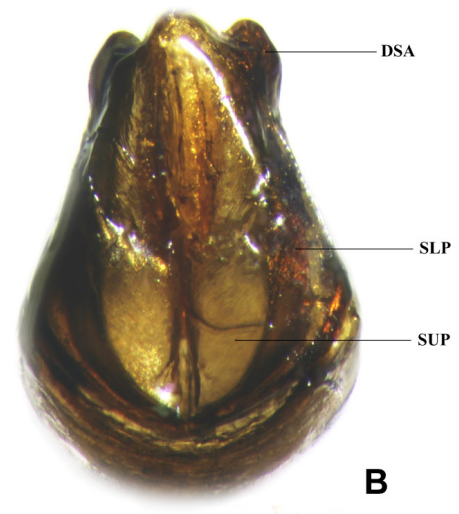

B

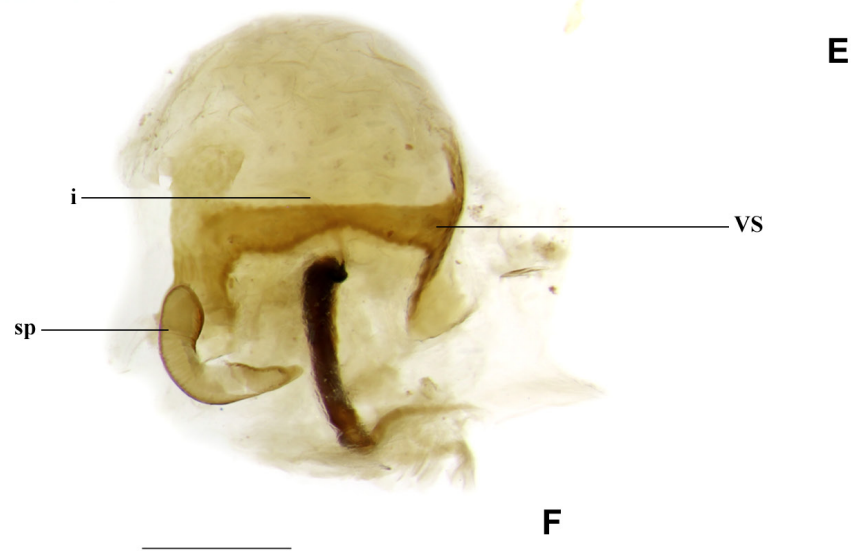

Fig. 1. A-B. Lateral and dorsal habitus of the parameres (Abbreviations: $\mathrm{Ph}=$ phallobase; $\mathrm{DPA}=$ distal-inferior paramerite; BLP = basolateral plate; SUP = superior plate; SLP = supralateral plate; DSA = distal-superior area). C, E. Frontal and posterior side of the internal sac (Abbreviations: LC = lamella copulatrix; $\mathrm{MK}=$ medial keel of the lamella copulatrix; $\mathrm{MKRl}=$ medial keel of the right lobe; $\mathrm{SL}=$ secondary lamella; $\mathrm{Ll}$ and $\mathrm{Rl}=$ left and right lobe of the lamella copulatrix; FLP = fronto-lateral peripheral lamella; $\mathrm{MP}=$ medial peripheral lamella; $\mathrm{SRP}=$ superior right peripheral lamella; $\mathrm{A}=$ axial lamella; SA = subaxial lamella). D. Rear view of the aedeagus with internal sac at rest; posterior side of the internal sac in transparency. F. Female genitalia (Abbreviations: $i=$ infundibulum; $s p=$ spermatheca (receptaculum seminis); VS = ventral sclerotization of the vagina). Scale bars: 0,05 mm. 


\section{Results}

The taxonomic revision led us to confirm the validity of 25 species names already proposed by Zunino \& Halffter (1997) for the hirculus group. Furthermore, at least 22 new species belonging to the same group have been identified, while five new synonymies must be established, and for practical usage, one of them will be discussed here.

During a recent visit to the Naturhistoriska Riksmuseet of Stockholm, FZVM and Mattias Forshage (NHRS) surprisingly rediscovered two specimens, male and female, belonging to the type series of Onthophagus hircus Billberg, 1815 and bearing a manuscript label "Rio Janeiro Kymell" (Fig. 2DE). These specimens apparently survived, together with a few other insects, from the fire that largely destroyed the Billberg collection in 1822 at the Museum of Stockholm (Smith 1986). According to Horn et al. (1990), Smith (1986) and M. Forshage (personal communication), all known type specimens of Billberg's first collection are today housed at the NHRS, while his second collection was sold in 1839/40 to J.L. Children and is currently at the NHMUK. Furthermore, Evenhuis (1997), quoting Smith (1986), wrote that 24 drawers of Billberg's insects were housed at the Oxford University Museum of Natural History (OUMNH). However, Mr D.J. Mann, currently Head of Life Collections at the OUMNH, confirmed to us that very few insects with a "Blbg" label (indicative sign of Billberg specimens) are deposited in their entomological collection, and no American Onthophagus seem to be present.

M. Forshage (unpublished) carried out an extensive biographical research on the Swedish entomologist, and recently found at the NHRS a copy of the Enumeratio Insectorum (Billberg 1820) containing several original notes of the author. Therein, Billberg listed the species of his first collection, reporting also the names of the species present in his second collection (assembled between 1822-1829). More importantly, Billberg specified that all the type specimens of the species he described in Schönherr $(1808,1817)$ were properly deposited in the collection of C.J. Schönherr, which had fortunately escaped the 1822 fire (confirmed by M. Forshage to MR).

Another very interesting fact is that most of the species described in Billberg (1815) were not found among the few specimens left in his first collection, now at the NHRS (Forshage personal communication). Surprisingly, Onthophagus hircus appears to be the only species still there. Today, nobody knows the fate of the remaining species described in Billberg (1815). However, in a paper on African tenebrionids, Ferrer (1991) decided to examine the Schönherr collection to look for the type specimens of some problematic species names described by Billberg (1815). As C.J. Schönherr was Billberg's brother-inlaw, Ferrer thought it very likely that the two entomologists could have exchanged specimens in the past. Indeed, as expected, Ferrer found all the tenebrionid specimens he was looking for. Likewise, M. Forshage (personal communication to MR) recently examined the Schönherr collection and found several specimens labelled as types and bearing the exact collection data provided by Billberg (1815).

Therefore, it might be probable that some syntypes of $O$. hircus are still preserved in Schönherr's collection and, according to Billberg's latest annotations (dated back to 1829 and today preserved in the library of the Coleoptera section of the NHRS), this species was also present in the lot of insects sold to J.L. Children (M. Forshage personal communication). In addition, it could be also speculated that Billberg donated or traded other syntypes of $O$. hircus with entomologists of that time, such as L. Gyllenhal, C.P. Thunberg (Zoological Museum of the University of Uppsala, as after all hypothesised by Boucomont 1932), C.G.G. Mannerheim (Helsinki) etc.

In view of this information, it makes sense to select one of the two specimens found at the museum of Stockholm as a lectotype of $O$. hircus, as they undoubtedly belong to the original type series and are today deposited at the NHRS, along with most of Billberg's type material. 
Onthophagus hircus Billberg, 1815 was mentioned by Gemminger \& Harold (1869), Boucomont (1932), Boucomont \& Gillet (1927), Blackwelder (1944) and Pulido-Herrera \& Zunino (2007). However, only the latter authors decided to consider this species name as nomen inquirendum, given the lack of evidence on its taxonomic identity. Boucomont (1932) included $O$. hircus in his synopsis and expressly stated to not have encountered any type specimens at the Museum of Uppsala. Relying on the only original description, Boucomont suggested that $O$. hircus could be $O$. bidentatus Drapiez, 1819. It is still unclear to us why A. Boucomont was searching for these type specimens in Uppsala. The only possible explanation is that over the years (from 1793 to 1817 according to the Swedish official biographical encyclopaedia (https://sok.riksarkivet.se/Sbl/Presentation.aspx?id=18212), Billberg continuously corresponded with K.P. Thunberg, then professor at the University of Uppsala, so Boucomont may have been aware that the two entomologists used to exchange natural history specimens.

However, our recent finding allowed us to reconsider $O$. hircus as a valid species name within the American dung beetle fauna, and the accurate examination of the syntypes of $O$. hircus and $O$. hirculus Mannerheim, 1829 (the latter deposited at the Finnish Museum of Natural History) allowed us to confirm that these specimens do indeed belong to the same species. Therefore, according to the principle of priority of the ICZN (1999: Art. 23), O. hirculus is treated here as junior synonym of O. hircus.

Class Hexapoda Blainville, 1816

Order Coleoptera Linnaeus, 1758

Family Scarabaeidae Latreille, 1802

Subfamily Scarabaeinae Latreille 1802

Tribe Onthophagini Burmeister, 1846

Genus Onthophagus Latreille, 1802

Onthophagus hircus Billberg, 1815

Fig. 2A-B, D-E

Onthophagus hircus Billberg, 1815: 274.

Onthophagus hirculus Mannerheim, 1829: 39, syn. nov. (Fig. 2C, F)

Regarding $O$. hirculus Mannerheim, 1829, we found one female specimen at MZH whose original labels (Fig. 2F) led us to consider this singleton as a syntype of this species name. Indeed, the "Ménétr" label refers undoubtedly to the French ornithologist and entomologist Edouard Ménétriés. From December 1823 to January 1824, Ménétriés was recruited by Baron G.H. von de Langsdorff to collect specimens around Tijuco (Minas Gerais) and particularly across the Serra da Lapa (Mannerheim 1829; see also Papavero 1971). Although Mannerheim in the original description of $O$. hirculus does not mention whether the specimens of the type series were collected by Ménétriés, he says the specimens were collected in Tijuco, which surely refers to the Arraial do Tejuco, the former name of the current municipality of Diamantina, Minas Gerais. According to Papavero (1971), the material collected by Ménétriés, de Langsdorff and Moritz Rugenda (the artist of the expedition) was partly sent to the Museum of Berlin, while 6 boxes of natural history specimens were sent to the Academy of Science of Saint Petersburg. The specimens belonging to the type series of $O$. hirculus were then incorporated into Mannerheim's personal collection, which is today deposited at MZH (Horn et al. 1990).

While the description of $O$. hirculus was based on at least one male and one female, we have so far not been able to find any male specimen attributable to the type series.

Thus, to preserve the nomenclatural stability for these species names, we designate as the lectotype of $O$. hircus the male belonging to the syntypic series, while the female is labelled as paralectotype. The only known surviving type specimen of $O$. hirculus is here designated as lectotype. 


\section{Material examined}

Lectotypes (here designated)

BRAZIL: Ō, Onthophagus hircus (NHRS), [Rio Janeiro, Kymell. (handwritten on white label)], [NHRSJLKB 000021091 (printed on white label)], [LECTOTYPE, Onthophagus hircus Billberg, des. F.Z. Vazde-Mello, 2013, ${ }^{\Uparrow}$ (printed and handwritten on red label with black border)].

BRAZIL: + , Onthophagus hirculus (MZH), [Ménétr. (printed in italics on white label)], [Brasilia, Minas Gerais (handwritten on cream label)], [o (handwritten on cream label)], [Onthophagus hirculus Mannerheim, 1829 (printed on white label)], [ID code, http://id.luomus.fi/GL.581 (printed on white label)], [LECTOTYPE, Onthophagus hirculus Mann., 1829, + , des. F.Z. Vaz-de-Mello, 2014 (printed and handwritten on red label with black border)].

\section{Paralectotype}

BRAZIL: + , Onthophagus hircus (NHRS), [Rio Janei., Kymell. (handwritten on white label)], [NHRSJLKB 000021092 (printed on white label)], [PARALECTOTYPE, Onthophagus hircus Billberg, des. F.Z. Vaz-de-Mello, 2013, , (printed and handwritten on yellow label with black border)].

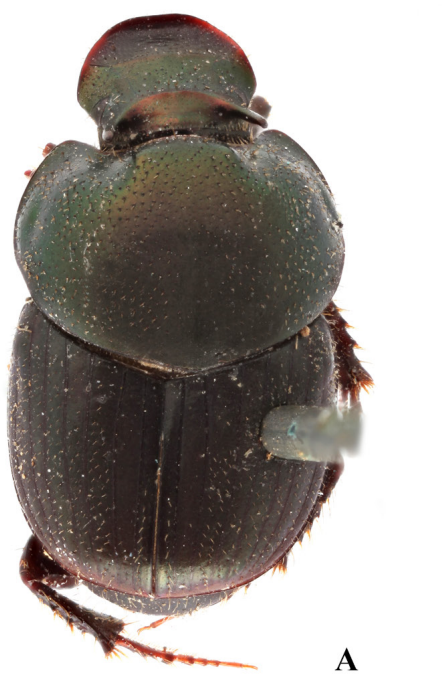

A

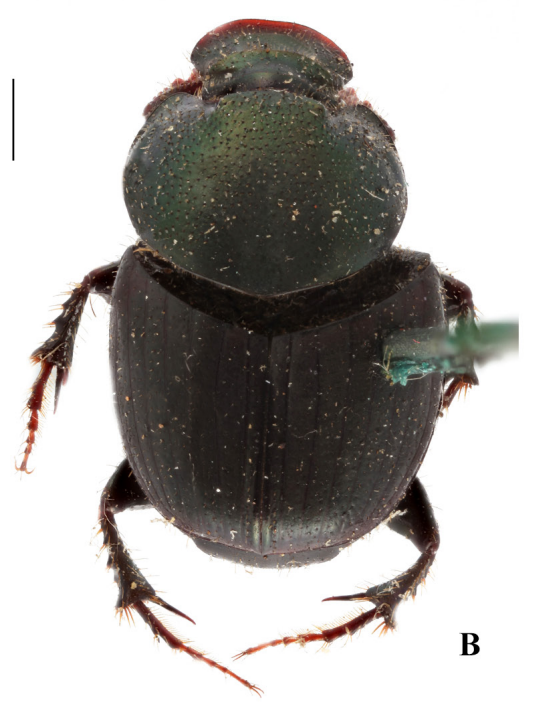

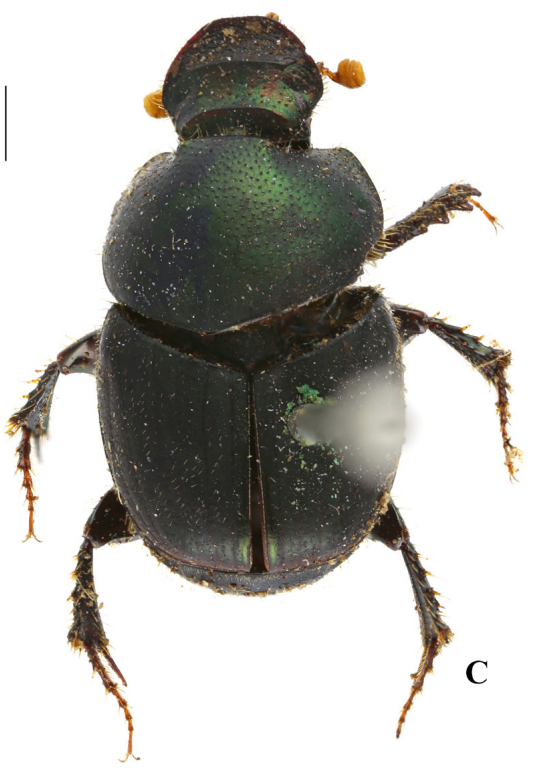

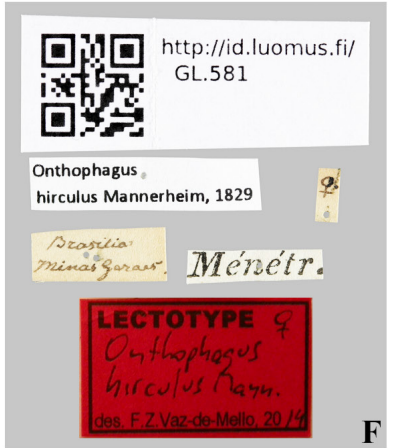

Fig. 2. A-B. Dorsal habitus of the lectotype and paralectotype of Onthophagus hircus Billberg, 1815. C. Dorsal habitus of the lectotype of $O$. hirculus Mannerheim, 1829. D-E. Labels of the types of O. hircus Billberg, 1815. F. Labels of the type of O. hirculus Mannerheim, 1829. 
According to these new nomenclatural arrangements, it is noteworthy to reconsider the name of the species group to which $O$. hircus belongs. Therefore, the hirculus group, as originally established by Zunino \& Halffter (1997), is here renamed the hircus group.

\section{Morpho-anatomical description of the hircus group}

Measurements. Small to large-sized species, body length 4-12 mm.

Colour. Body either evenly coloured (completely black, blue, brownish or dark green with strong greenish, blue or cupreous sheen) or pronotum and elytra of different colours (pronotum bronze, metallic green or dark brown, or pronotal disc metallic green or cupreous with sides yellowish, elytra black to dark brown, with paler or darker spots at the base, apex or middle, or elytral interstriae with alternate colours). Pygidium same colour as body or lighter, sometimes dark with paler spots. Ventral side of body black or reddish brown, some species with yellowish to brownish areas on sternites, metasternum, middle and hindfemurs. Tegument of the body either smooth or very finely microreticulated, shining to opaque and sericeous with greenish, bluish or silver iridescence, punctuation either simple and very fine or coarse and deep, some species with punctures associated with distinct granules and conspicuous setae.

HEAD. Margins strongly sinuated to evenly curved, clypeus trapezoidal, obtusely squared or triangular, genal and clypeal margins continuous or genae clearly expanded beyond clypeus (head margin notched at the clypeo-genal junction), clypeus weakly to strongly reflexed at middle, plate-like to acuminated and narrowly rounded. Male with fronto-clypeal carina entire or interrupted at middle, with transversal ridge or lacking any structure, male with frontal horns either shorter than upper side of pronotum or longer and widely curved. Horns simple, triangular, conical or clearly expanded at base (carinate), parallel to divergent, inclined backward or bowed forward at apex, some species with a central carina between horns. Head of female always with distinct fronto-clypeal carina, low or distinctly higher at middle, frons with carina between eyes, straight to feebly curved forward, depressed, interrupted, inclined backward or with tubercle at middle. Articles of antennal club either normal or distinctly elongated.

THORAX. Posterior margin of pronotum with border evanescent near posterior angles, lateral margins evenly curved, either almost straight, but convergent or distinctly concave near anterior angles. Anteromedial pronotal protuberance of male widely rounded, triangular, squared, conical or shelf-like and horizontally extended above head, two specimens with a pair of tubercles on the anteromedial region. Dorsal side of protuberance distinctly depressed, flattened or evenly and slightly convex. Female with anteromedial protuberance of pronotum always transversal, curved, straight or widely concave at middle, with both sides simple or tuberculate. Elytral striae usually very shallow and interstriae flat to very weakly convex, interstrial punctuation fine and sparse or punctures aligned in two to three rows, often associated with small granules and pale setae. Anterior side of propleuron slightly excavated to convex, either simple or with a small and acuminated tubercle in proximity of anterior angles of pronotum. Metasternum simply swollen between mesocoxae or with longitudinal and short keel, metasternal tegument with stronger punctures near mesocoxae to finely and sparsely punctuated.

AbDomen. Pygidium always completely bordered, with a fine ridge carina-like between pygidium and propygidium, pygidial surface flattened to slightly convex, punctures of different sizes, strong to obsolete, sparse or well distributed, most of punctures associated with short and straight setae. Pygidial tegument often completely and finely microreticulated, sometimes microreticulation restricted to the basal region.

LEGS. Foretibiae of male slender and more elongated than those of female, apical and internal tooth either acuminate or blunt, apical margin of protibiae with a few straight setae, apical spur curved downward, 
tip obtuse to acute, foretibiae always with four external teeth. Foretibiae of female unmodified, larger than those of male and not very elongated, external teeth stronger. Middle and hindlegs unmodified.

Male genitalia. In lateral view, parameres either elongated or fairly short compared to length of phallobase, basolateral plate straight to strongly excavated at middle, distal-inferior paramerites either very feebly curved or strongly bent downward. In dorsal view, distal superior area of parameres with lateral margin evenly curved, obtusely angulate or strongly acuminate, anterior margin curved, sinuate or transversally truncated. In frontal view, lamella copulatrix with superior left lobe either clearly emarginated or transversally truncate on the external side, very reduced, narrow and elongated downward or very wide. Lateral margin of the superior left lobe normal to clearly bent inward, apex of lobe acuminated, obtuse and lobate or truncate. Inferior right lobe elongated downward and normal or short and with a distinct keel plate-like on the external margin. Medial keel of lamella copulatrix either wide or very reduced. Secondary lamella either squared with lateral margins parallel or very elongated and distinctly narrower at middle, superior side either normal or with a low keel.

Female genitalia. Ventral sclerotization of vagina distinct to very weakly defined, central region wide to very narrow, with inferior margin either normal or distinctly sinuate. Distal portion of the infundibulum little developed in length.

\section{Distribution}

Species of the hircus group are distributed from the northern United States (Wisconsin according to Howden \& Cartwright (1963); although the authors do not provide the exact locality, its position onto the map appears to be located far north with respect to the Canadian (mostly south of Toronto) and USA localities recorded in our study to central Argentina (San Luís Province), with the highest diversity across the Mexican Transition Zone, as well as the Brazilian and Chacoan sub-regions, which refer to the geographical space occurring from central and southern Mexico to most of continental South America (Fig. 4).

\section{Taxonomy of the hircus group}

While informative morphological characters for taxonomic and phylogenetic purposes have been sought on several body parts of the beetles, including wings and mouthparts, the morpho-anatomical traits observed on the external body and genital organs revealed to be very useful in defining five speciescomplexes, whose taxonomy and geographical ranges are provided below (names, descriptions and illustrations of new species, as well as new synonymic notes will be provided in forthcoming articles):

\section{Curvicornis complex}

Onthophagus curvicornis Latreille, 1809, O. incensus Say, 1835, O. nitidior Bates, 1886, O. stockwelli Howden \& Young, 1981, O. batesi Howden \& Cartwright, 1963, O. janthinus Harold, 1875, O. acuminatus Harold, 1880, O. tristis Harold, 1873, O. striatulus striatulus (Palisot de Beauvois, 1809), O. striatulus floridanus Blatchley, 1928. Six new species have been identified within the complex.

\section{Hircus complex}

Onthophagus hircus Billberg, 1815, O. ptox Erichson, 1847, O. aeneus Blanchard, 1846, O. bidentatus Drapiez, 1819, O. marginicollis Harold, 1880, O. antillarum Arrow, 1903, O. buculus Mannerheim, 1829, O. ranunculus Arrow, 1913. At least five new species must be included in this complex.

\section{Ophion complex}

Onthophagus ophion, Erichson, 1847 and five new species to be described. 


\section{Osculatii complex}

Onthophagus osculatii Guérin-Méneville, 1855, O. nyctopus Bates, 1886, O. steinheili Harold, 1880, O. transisthmius Howden \& Young, 1981, O. ophion confusus sensu Boucomont, 1932 [species propria], O. insularis Boheman, 1858, O. basicarinatus Rossini, Vaz-de-Mello \& Zunino, 2018 and $O$. chacoensis Rossini, Vaz-de-Mello \& Zunino, 2018.

\section{Rubrescens complex}

Onthophagus rubrescens Blanchard, 1846, O. haematopus Harold, 1875, O. onorei Zunino \& Halffter, 1997. At least four new species must be included in this complex

\section{Remarks}

The publication dates of the species authored by Blanchard (i.e., O. aeneus and $O$. rubrescens) and Latreille (O. curvicornis) are corrected according to Evenhuis (1997) and Bousquet (2016), respectively.

Unlike Zunino \& Halffter (1997), we did not include O. crinitus Harold, 1869 and its subspecies O. crinitus panamensis Bates, 1886 in the hircus group, as their external morphology and genital organs lead us to consider them to be related to the species of the gazellinus group (comments based on the ongoing revision of the species group).

Furthermore, O. embrikianus Paulian, 1936, O. nabeleki Balthasar, 1939, O. schunckei Paulian, 1936 and O. catharinensis Paulian, 1936, which were considered valid species names within the hircus group by Zunino \& Halffter (1997), are here considered to be junior synonyms of species assigned to this group. These synonymies will be properly discussed throughout the taxonomic revision of the speciescomplexes.

\section{Identification key to the species-complexes of the hircus group}

1. Foretibia of male very slender and elongated, apical and internal margin with a distinct and acuminate tooth (Fig. 3A). If foretibia of male lacks a distinct apical tooth, then cephalic horns short, triangular and placed in the midline of the eyes (Costa Rica), body metallic blue (southeastern Brazil) or covered by long and dense hairs (southeastern Brazil to Uruguay). Pronotal punctures either simple or associated with small granules (one species and its subspecies from USA). From northern USA to northern Peru (through northern Venezuela), two species from southeastern Brazil to northern Uruguay ........curvicornis complex

- Foretibia of male not very elongated, apical and internal tooth obtuse to obsolete (Fig. 3B). If foretibia of male very slender and with apical tooth acuminated, then cephalic horns strongly curved and embracing pronotal protuberance, always placed near the posterior side of the eyes (one species from Ecuador and Peru). Body neither metallic blue nor covered by long hairs. Body simply punctuated, granulated or with asperous punctures. From Central (Costa Rica) to South America, including Lesser Antilles ..................2

2. At least apex of elytra with granulose to asperous punctures associated with short and straight setae (Fig. 3C). If elytral interstriae devoid of any granules, then male with a central carina between cephalic horns (one species from Peru and Bolivia). Elytra either single-coloured (black, testaceous, dark brown, dark green) or odd interstriae clearly darker (Fig. 3C). Elytral tegument opaque to very weakly shining. From Panama to central Argentina ................hircus complex

- Elytra without granules or asperous punctures, conspicuous setae - when present - only associated with the punctures of lateral interstriae (VI-VII). Cephalic horns of male not connected by a central carina. Elytral interstriae never with alternate colours, either evenly coloured or disc clearly lighter than borders, some species with paler to reddish spots at the base and apex (Fig. 3D-E) .........3 

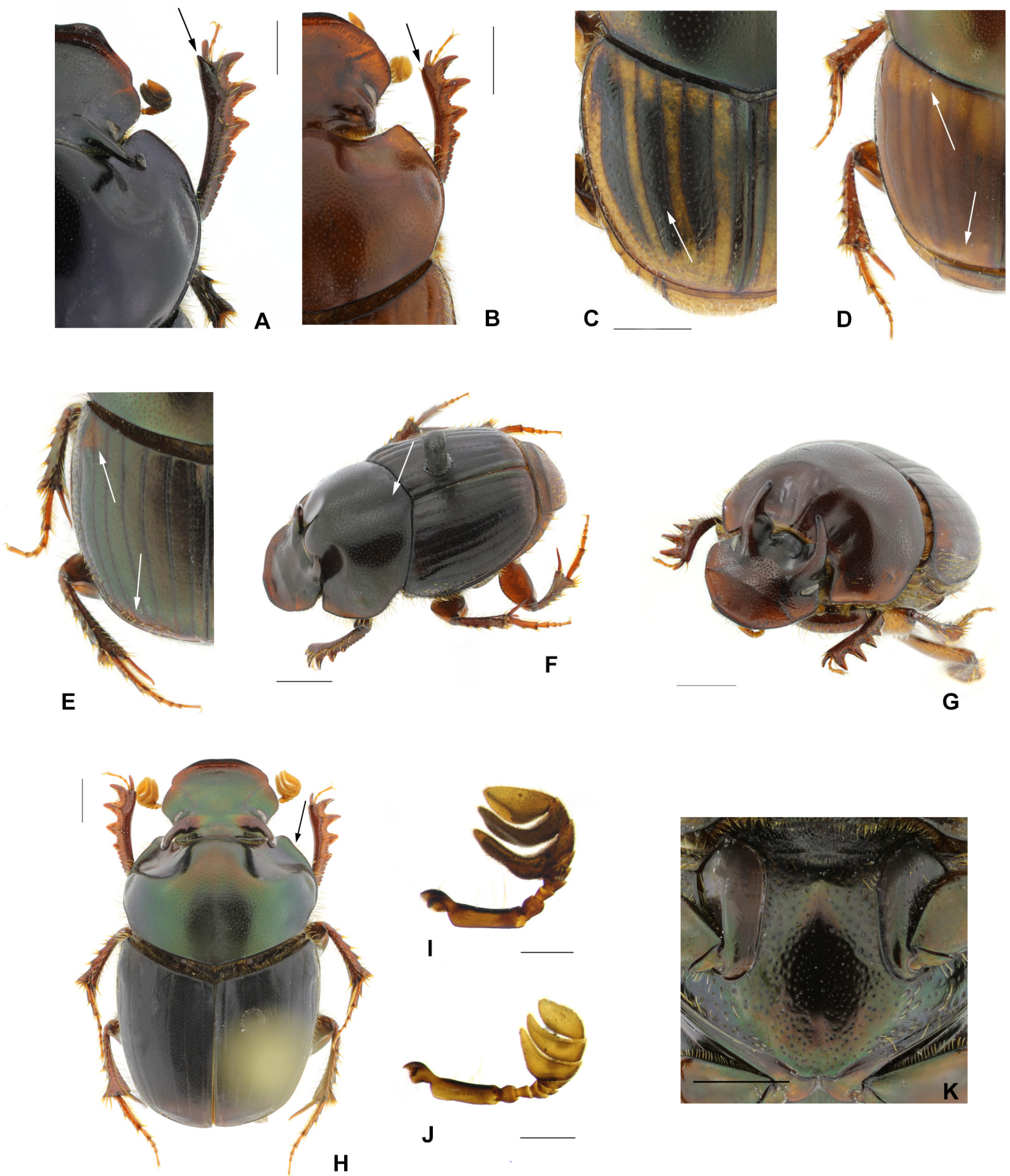

Fig. 3. A. Protibial apical tooth acuminate. B. Protibial apical tooth obtuse. C. Details of the elytral interstriae of Onthophagus marginicollis Harold, 1880 (hircus complex). D-E. Detail of the elytral paler spots. F. Pronotal sulcus of O. haematopus Harold, 1875 (rubrescens complex). G. Detail of the basal carina of the cephalic horns. H. Shape of the clypeus and lateral margin of pronotum of a species of the ophion complex. I. Right antenna of species of the ophion complex. J. Right antenna of species of the osculatii complex. K. Detail of the metasternal punctuation of a species of the osculatii complex. Scale bars: $1 \mathrm{~mm}$. 
3. Clypeus of male always triangular and elongated forward, clypeal margin truncated to narrowly rounded at middle, cephalic horns simple, straight and slightly bowed forward or feebly curved inward. Pronotum always with a longitudinal and distinct sulcus at least on the posteromedial region (Fig. 3F). Elytra shining, one species with discal interstriae (I-III) slightly opaque (Peru). Small to medium-sized species (body length 4-7 $\mathrm{mm}$ ). Body reddish brown to black with reddish spots on the humeral umbones, or pronotum metallic dark-green and elytra black to testaceous on the disc and darker at the borders. From northern South America (Colombia, Venezuela and Guianas) to northern Argentina rubrescens complex

- Clypeus of male evenly curved, sub-trapezoidal or squared, if triangular, then major male either with cephalic horns carinate at the base (Fig. 3G) or pronotum not distinctly sulcate (at most slightly flattened or very weakly sulcate on the posteromedial region). Elytra opaque, sericeous to feebly shining, always entirely microreticulated ......................................

4. Clypeus of male wide, curved to obtusely squared (Fig. 3H), fronto-clypeal carina always absent in major male. Cephalic horns simple and slightly curved. Lateral margins of pronotum either evenly curved or slightly concave near anterior angles (Fig. $3 \mathrm{H}$ ), anteromedial pronotal protuberance widely rounded between cephalic horns. Articles of the antennal club elongated (Fig. 3I); if antennal club normal, then basal half of elytra orange to testaceous and apex black. From Ecuador to Bolivia, one species known from the Guiana Shield ophion complex

- Clypeus of male slightly elongated forward, triangular, trapezoidal or curved, male of two species with fronto-clypeal carina. Cephalic horns straight to very strongly curved and embracing the pronotal protuberance, one species with horns carinate at the base (Fig. 3G). Lateral margins of pronotum always evenly curved, anteromedial pronotal protuberance narrowly rounded, conical or very weak between cephalic horns; if widely rounded, then metasternal disc strongly punctuated (Fig. 3K). Articles of the antennal club normal (Fig. 3J). From Costa Rica to Bolivia, two species reaching eastern Amazonia osculatii complex

\section{Remark}

The northern distribution of the osculatii complex is still rather doubtful, as throughout our extensive study we found an old specimen of O. nyctopus from Mexico (Sonora), which is here considered to be a possible mislabelling. So, at this stage, we prefer to consider the Costa Rican localities to be the northernmost limits of distribution of this complex. Nevertheless, the question is discussed more in depth in the taxonomic revision of the osculatii complex (Rossini et al. 2018).

\section{Discussion}

Recently published morphological and molecular phylogenies, as well as biogeographic inferences, revealed fairly discordant hypotheses about direct relationships between American Onthophagus and external lineages (see Emlen et al. 2005; Tarasov \& Solodovnikov 2011; Philips 2016; Breeschoten et al. 2016). Nevertheless, we deem these studies - with the exception of Emlen et al. (2005), who quoted Matthews (1972) and Zunino \& Halffter (1997) in a footnote - would have been improved if earlier works had been taken into account.

The phyletic relationships of the American Onthophagus and their inclusion in the subgenus Onthophagus s. str. (sensu Zunino 1979) were first suggested by P. Varola (1980). The in-depth analysis of the genital organs of a representative biogeographic sample of 47 species from the New World, and also species from the Palearctic and Oriental regions, the Chinese transition zone and south-east Asia, led the author to hypothesize a northern origin (northeastern Palearctic-northern North America) for the American Onthophagus. The argument was subsequently addressed by Zunino \& Halffter $(1981,1988)$, who remarked upon the extra-American origin of the New World Onthophagus and the colonization 
of the American continent through the Beringian land bridge. They also suggested that the complex evolutionary history and differentiation of the group within the American continent may have occurred in different periods and from different ancestors - all of them belonging to the subgenus sensu stricto. Thus, the radiation of the genus in the New World appears to have been driven by north-south climatic changes, a phenomenon that was described by one of us as dynamic vicariance (Zunino 2000, 2003).

According to Halffter (1987) and Zunino \& Halffter (1988), the American Onthophagus can be considered to be relatively recent products of the evolutionary history of the nominotypical subgenus, which is likely to have originated in the eastern Palearctic/Chinese transition zone (see also Palestrini 1985). However, the evolutionary history of the genus on the American continent is yet to be resolved, as its systematics still needs to be thoroughly investigated. So, the question about the possible internal phyletic homogeneity or the occurrence of more than a single lineage within the American Onthophagus

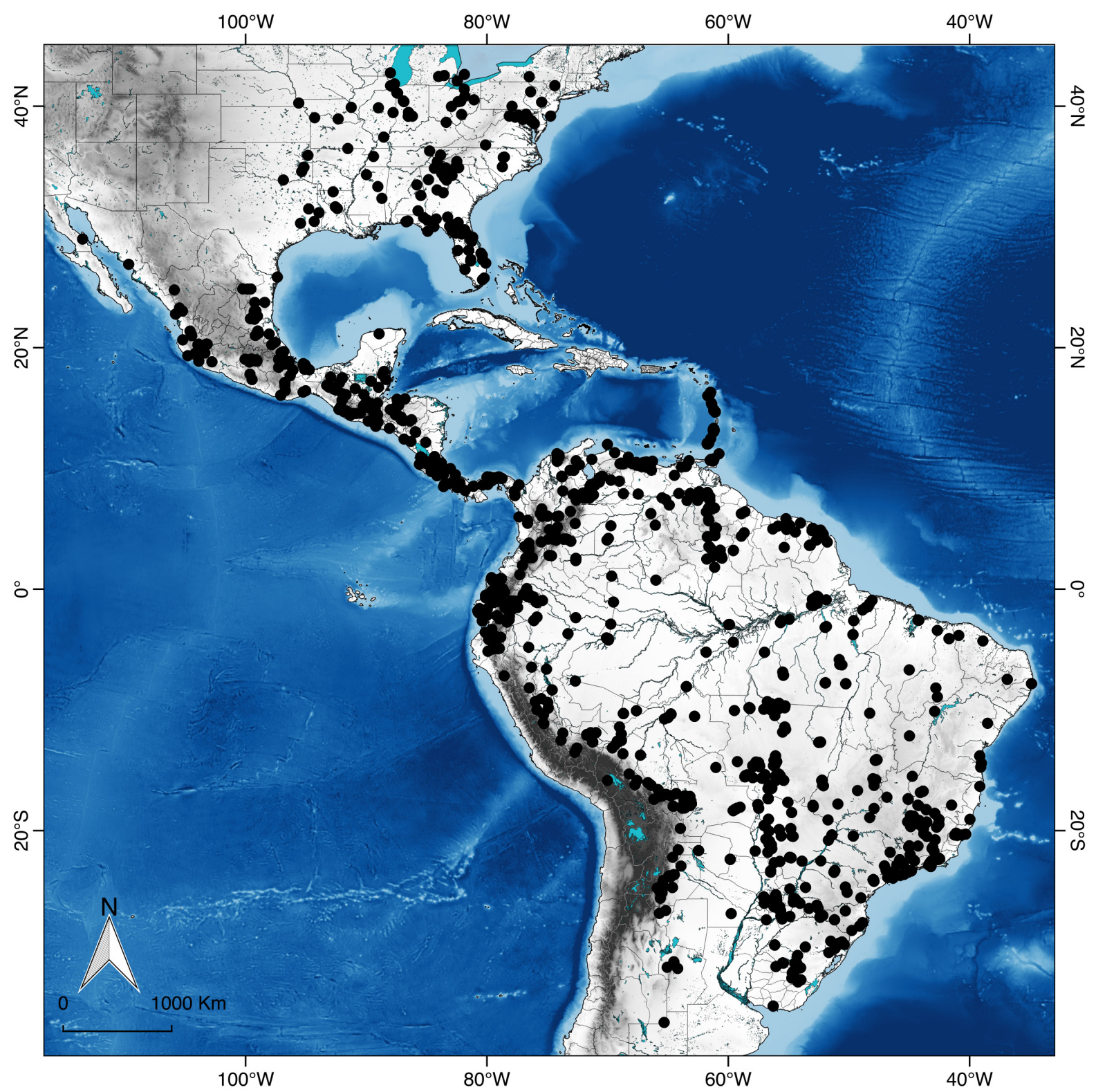

Fig. 4. Geographical range of the hircus group. 
is still controversial, even though to date the first hypothesis seems to be very unlikely (see also Scotese 2004; Halffter \& Morrone 2017; Halffter 2017).

According to the molecular-based phylogeny proposed by Breeschoten et al. (2016), the New World Onthophagus would form a monophyletic group, while the Australian Onthophagus appear to be represented by a single or two closely related clades, one of them having sister relationships with the American group. In her M.Sc thesis, C. Palestrini (1980) examined the male and female genital armours of 76 Australian Onthophagus following the systematics proposed by Matthews (1972) and, according to her results, almost the entire sample of species was considered to belong to the nominotypical subgenus or, at most, to an Oriental group that shared close relationships with it. Importantly, in the same work the author emphasized the strong interspecific variability observed in the genitalia of the Australian species compared to the New World Onthophagus. The results of both P. Varola and C. Palestrini's theses were briefly reported and discussed by Palestrini (1985) at the XIV Congresso Nazionale Italiano di Entomologia (Fig. 5).

According to our results, the hircus group can be still considered as the most species-rich within the American Onthophagus. Its distributional range encompasses the largest geographic area when compared to the other species-groups identified within the genus in America (Fig. 4). The distribution of the hircus group across the northernmost part of its geographic range, which is occupied by O. striatulus striatulus, $O$. striatulus floridanus and partly by $O$. batesi, appears to be constrained to the easternmost part of the USA. This distribution, which is roughly limited to the west by meridian 100, may represent the most recent biogeographic framework possibly moulded by a series of paleogeographic and paleoclimatic events, which involved the drying of the Western Interior Seaway and consequent climatic and environmental changes (Late Cretaceous). Furthermore, Quaternary glaciations, which undoubtedly caused a discontinuous succession of marine transgression-regression events, as well as fluvial sedimentation in the southern part of the Mississippi River and Rio Bravo (Curray 1960; Sager et al. 1992; Bentley et al. 2016; C.R. Scotese, W.F. Hansen, J.A. Green personal communications to $\mathrm{MZ}$ ), may have favoured the disjunction of the northern part of the distribution area of the hircus group.

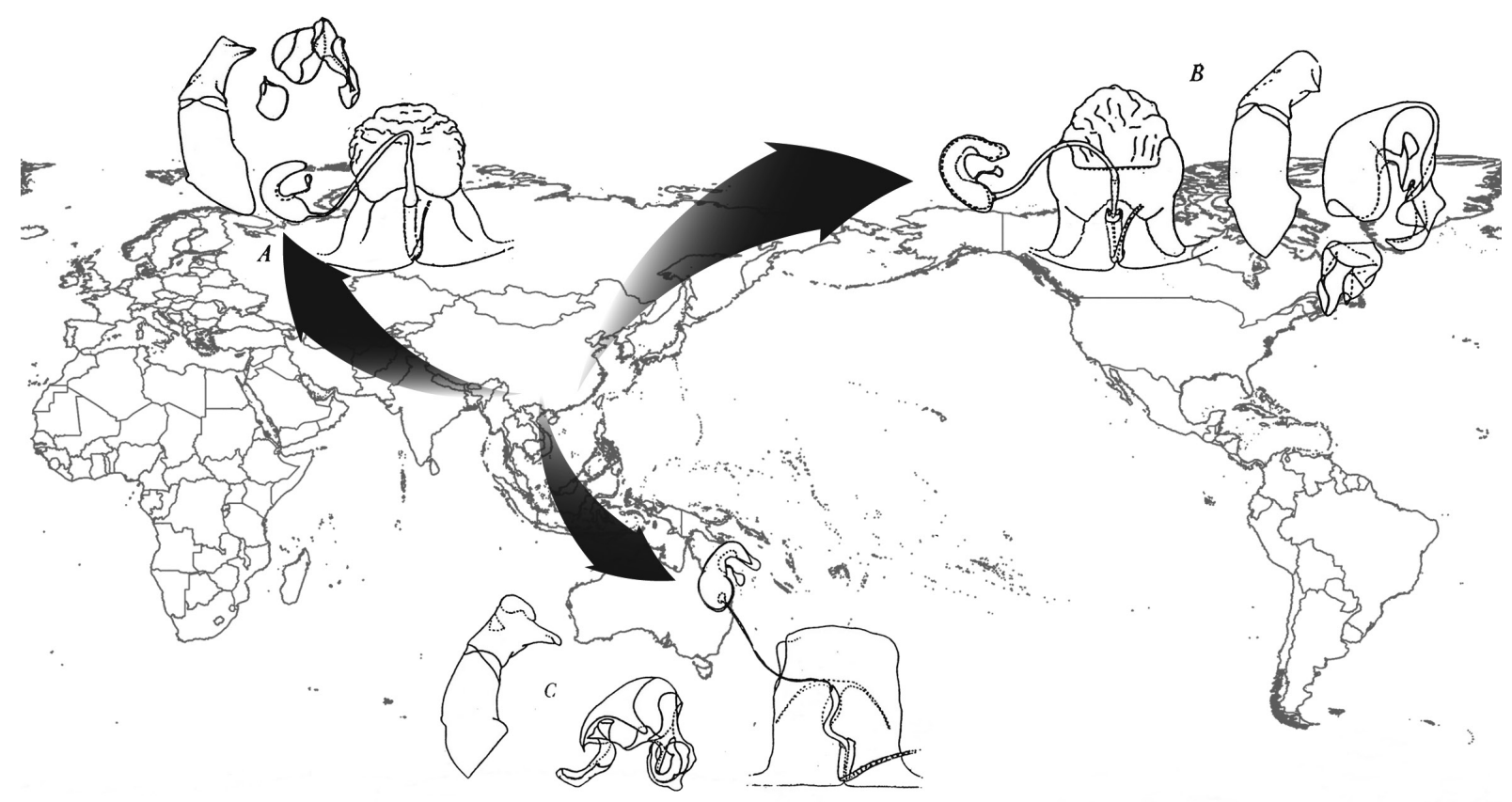

Fig. 5. Hypothetical dispersion/dispersal of Onthophagus s.str. Latreille, 1802, modified after Palestrini (1985). The map is based on the current geography of the continents. 
A succession of diachronic disjunctions was also suggested for the American Geotrupinae distributed in the same region (Zunino 1984).

With its northern and southern limits of distribution, the hircus group today almost encompasses the entire geographic range of the American Onthophagus (see Fig. 4 and Zunino \& Halffter 1997). The only exception is the northern boundary, as $O$. orpheus (mexicanus group) has been recorded from southern Manitoba (O. orpheus pseudorpheus Howden \& Cartwright, 1963) and southern Ontario (O. orpheus canadensis (Fabricius, 1801)) (Howden \& Cartwright 1963).

The southernmost boundaries of the hircus group appear to follow the limits of environmental resistance already proposed by Ruggiero et al. (1998) and then reported in Morrone (2007). Indeed, according to our current knowledge, the species group does not expand qualitatively and quantitatively beyond these lines (Fig. 6), which correspond to the boundaries drawn by different authors (from Sclater 1858 onwards) between the Neotropical region sensu stricto and the Andean-Patagonian region (or sub-region; this is also named in literature as South American transition zone (Morrone 2007, 2009)) (Fig. 7). Furthermore, in the light of the present geographical distribution of the hircus group across its southernmost limits, it is noteworthy to remark the importance of a series of geological events and consequent climatic changes that occurred in South America over the last $65 \mathrm{Ma}$. These events were responsible for successive phases of marine transgressions and regressions, which occurred across the Pacific and Atlantic shorelines (Ortiz-Jaureguizar \& Cladera 2006). In particular, three main marine transgression events led to the formation of epicontinental seas that invaded South America from the south-east to the north-west, dividing the continent into two major regions. Chronologically, the socalled Salamancan (Late Cretaceous), Patagonian (Late Oligocene-Early Miocene) and Paranean seas (Late Miocene) flooded the eastern coasts of South America from the current delta of Rio de La Plata, either reaching southern Peru or northern Colombia (Paranean sea). Therefore, the cyclic occurrence/

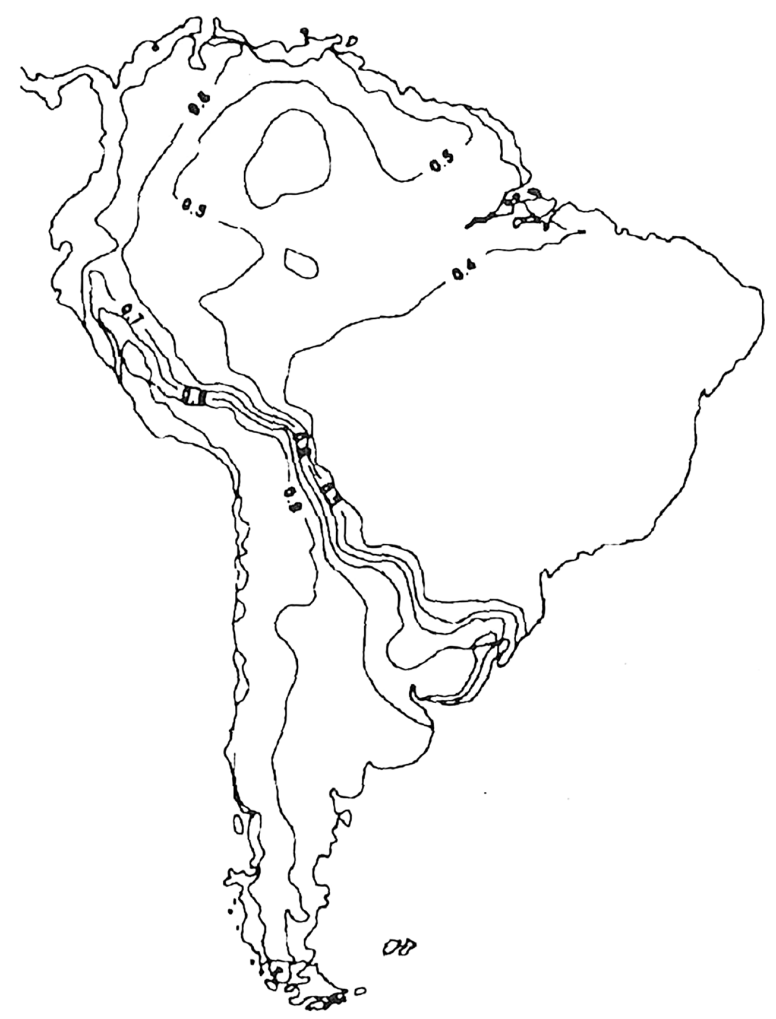

Fig. 6. Spatial patterns of variation in the environmental resistance separating the Neotropical region s.str. and the Andean region (see main text) (from Morrone 2007). 
disappearance of epicontinental seas onto the land, the distinct climatic conditions established at both sides of these seas and the successive climatic changes during marine regression events might have repeatedly favoured the expansion and contraction of the distribution area of different organisms.

Finally, as demonstrated by the present contribution on the New World Onthophagus, we would like to point out the importance of descriptive taxonomic surveys to provide a more reliable understanding of the real diversity of this still very enigmatic taxon.

The comprehensive taxonomic revision of the hircus group led us to recognize five species-complexes that represent, in our opinion, elements of high morphological and biogeographic cohesion to be considered separately within the group.

Nevertheless, the monophyletic status of the group and its species complexes, as well as their respective phylogenetic relationships, will be addressed in forthcoming articles.

\section{Acknowledgements}

We would like to thank all the curators and private individuals who gave us access to the natural history collections here examined. Special thanks go to Mattias Forshage (NHRS), who gave us very important information on Billberg's biography and collections. To L. Balsamini, G. Galassi, J.A. Green, W.F. Hansen, C.R. Scotese and G. Spada, for providing us with valuable information and literature. We want also to express our gratitude to Dr B.D. Gill, Honorary Research Associate at the Canadian Food Inspection Agency, who kindly revised the English of this paper. MR was supported by a MIUR PhD scholarship (Ministero dell'Istruzione, della Ricerca e dell'Università) and partly by external

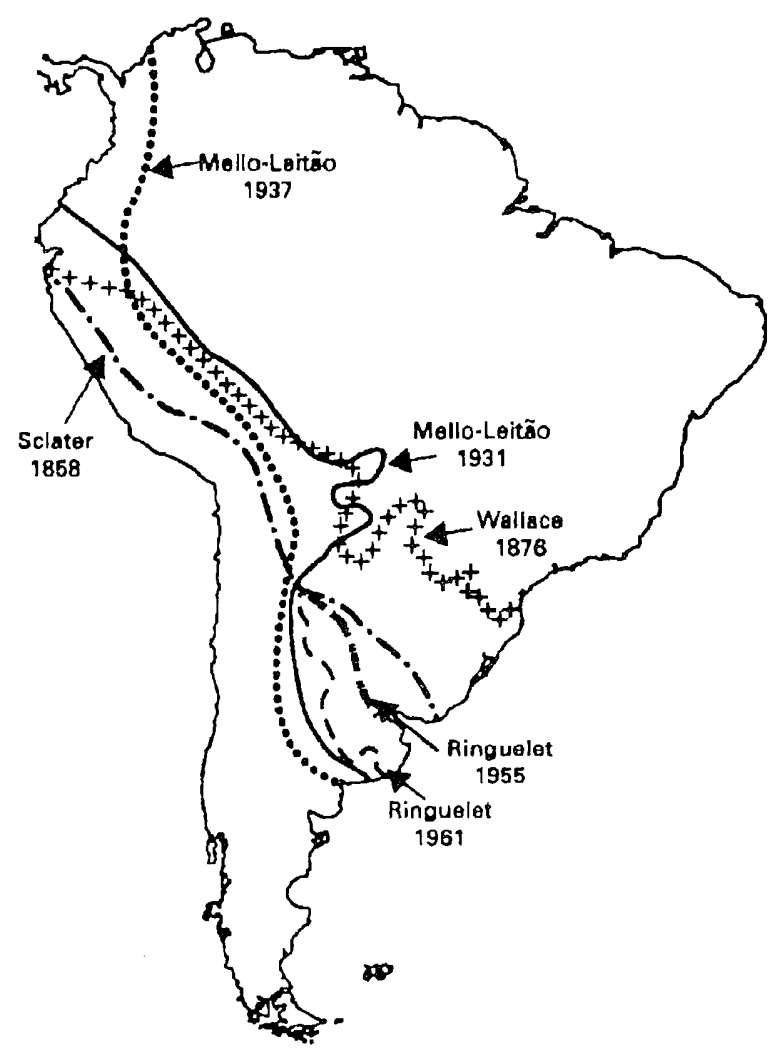

Fig. 7. Limits between Guianan-Brazilian and Andean-Patagonic sub-regions according to several authors (from Morrone 2007). 
grants (Synthesys, Ernst Mayr Travel Grant, CanaColl Foundation research grant). FZVM is a CNPq (Conselho Nacional de Desenvolvimento Científico e Tecnológico) fellow and parts of this work were funded by CNPq: 302997/2013-0, 304925/2010-1, 484035/2013-4, 405697/2013-9 and 440604/20150) PPBio/CNPq 248299/2012-3, FAPEMAT/CNPq PRONEM 568005/2014, ISYEB, UMR 7205 CNRS/MNHN and INCT-CENBAM/CNPq. Parts of this research were also granted by the Synthesys Project (http://synthesys3.myspecies.info/), which is financed by the European Community Research Infrastructure Action under the FP7 (MR: FR-TAF-3664; SE-TAF-6016; FZVM: GB-TAF-3855). MZ is a recently retired Full Professor of Zoology, University of Urbino, free researcher collaborating with the Scuola di Biodiversità - Polo universitario Asti Studi Superiori, Italy.

\section{References}

Bentley S.G. Sr., Blum M.D., Maloney J., Pond L. \& Paulsell R. 2016. The Mississippi River source-tosink system: perspectives on tectonic, climatic, and anthropogenic influences, Miocene to Anthropocene. Earth-Science Reviews 153: 139-174. https://doi.org/10.1016/j.earscirev.2015.11.001

Billberg G.J. 1815. Insecta ex ordine coleopterum descripta. Nova Acta Regiae Societatis Scientiarum Upsaliensis 7: 271-281.

Billberg G.J. 1820. Enumeratio insectorum in Museo Gust. Joh. Billberg. Gadelianis, Stockholm.

Binaghi G., Dellacasa G. \& Poggi R. 1969. Nuovi caratteri diagnostici per la determinazione degli Onthophagus del gruppo ovatus (L.) e geonemia controllata delle specie italiane del gruppo. Memorie della Società Entomologica Italiana 48: 29-46.

Blackwelder R.E. 1944. Checklist of the coleopterous insects of Mexico, Central America, the West Indies, and South America. Part 2. United States National Museum Bulletin 185: 189-341. https://doi.org/10.5479/si.03629236.185.2

Boucomont A. 1932. Synopsis des Onthophagus d'Amérique du Sud (Col. Scarab). Annales de la Société entomologique de France Paris 101 (4): 293-332. Available from http://gallica.bnf.fr/ark:/12148/bpt6k54613496 [accessed 28 Mar. 2018].

Boucomont A. \& Gillet J.J.E. 1927. Fam. Scarabaeidae, Subfam. Coprinae II. Coleopterorum Catalogus 19 (90): 103-263.

Bousquet Y. 2016. Litteratura Coleopterologica (1758-1900): a guide to selected books related to the taxonomy of Coleoptera with publication dates and notes. Zookeys 583: 1-776.

https://doi.org/10.3897/zookeys.583.7084

Breeschoten T., Doorenweerd C., Tarasov S. \& Vogler A.P. 2016. Phylogenetics and biogeography of the dung beetle genus Onthophagus inferred from mitochondrial genomes. Molecular Phylogenetics and Evolution 105: 86-95. https://doi.org/10.1016/j.ympev.2016.08.016

Curray J.R. 1960. Sediments and history of Holocene transgression, continental shelf, northwest Gulf of Mexico. In: Shepard F.P., Phleger F.B \& Van Andel T.H. (eds) Recent Sediments, Northwest Gulf of Mexico: 221-266. The American Association of Petroleum Geologists, Tulsa, Oklahoma, USA.

Delgado L. \& Curoe D.J. 2014. Panamanian Onthophagus (Coleoptera: Scarabaeidae): description of a new species and a revised key to the species. Florida Entomologist 97 (1): 61-67.

Emlen D.J., Marangelo J., Ball B. \& Cunningham C.W. 2005. Diversity in the weapons of sexual selection: horn evolution in the beetle genus Onthophagus (Coleoptera: Scarabaeidae). Evolution 59: 1060-1084. https://doi.org/10.1111/j.0014-3820.2005.tb01044.x

Evenhuis N.L. 1997. Litteratura taxonomica dipterorum (1758-1930). Volumes I-II. Backhuys, Leiden, The Netherlands. 
Ferrer J. 1991. Rediscovery of type material of Gustav Johan Billberg (1815) in the Naturhistoriska Riksmuseet, Stockholm (Coleoptera: Tenebrionidae). Annals of the Transvaal Museum 35 (19): 279283.

Gemminger M. \& Harold von E. 1869. Catalogus Coleopterorum hucusque descriptorum synonymicus et systematicus. Vol. 4: Scarabaeidae. Sumptu E.H. Gummi, Munich, Germany.

https://doi.org/10.5962/bhl.title.9089

Génier F. \& Howden H.F. 1999. Two new Central American Onthophagus Latreille of the mirabilis species group (Coleoptera: Scarabaeinae: Scarabaeidae). Coleopterists Bulletin 53 (2): 130-144.

Génier F. \& Howden H.F. 2014. Onthophagus fragosus n.sp. a second endemic species of Onthophagus Latreille from Cuba (Coleoptera: Scarabaeidae: Scarabaeinae). Zootaxa 3795 (5): 597-599. https://doi.org/10.11646/zootaxa.3795.5.10

Halffter G. 1987. Biogeography of the montane entomofauna of Mexico and Central America. Annual Review of Entomology 32 (1): 95-114. https://doi.org/10.1146/annurev.en.32.010187.000523

Halffter G. 2017. La zona de transición mexicana y la megadiversidad de México: del marco histórico a la riqueza actual. Dugesiana 24 (2): 77-89.

Halffter G. \& Morrone J.J. 2017. An analytical overview of Halffter's Mexican transition zone and its relevance for evolutionary biogeography, ecology and biogeographical regionalization. Zootaxa 4226 (1): 1-46. https://doi.org/10.11646/zootaxa.4226.1.1

Horn W., Kahle I., Friese G. \& Gaedike R. 1990. Collectiones entomologicae. Ein Kompendium über den Verbleib entomologischer Sammlungen der Welt bis 1960. Teil I: A bis K; Teil II: L bis Z. Akademie der Landwirtschaftswissenschaften der DDR, Berlin.

Howden H.F. \& Cartwright O.L. 1963. Scarab beetles of the genus Onthophagus Latreille north of Mexico (Coleoptera: Scarabaeidae). Proceedings of the United States National Museum 114 (3467): 1-133. https://doi.org/10.5479/si.00963801.114-3467.1

Howden H.F. \& Gill B.D. 1993. Mesoamerican Onthophagus Latreille in the dicranius and mirabilis species groups (Coleoptera: Scarabaeidae). The Canadian Entomologist 125: 1091-1114.

https://doi.org/10.4039/ent1251091-6

Howden H.F. \& Young O.P. 1981. Panamanian Scarabaeinae: taxonomy, distribution and habits (Coleoptera: Scarabaeidae: Scarabaeinae). Contributions of the American Entomological Institute 18 (1): 1-204.

ICZN (International Commission on Zoological Nomenclature). 1999. International Code of Zoological Nomenclature. 4th Edition. The International Trust for Zoological Nomenclature, London.

Kohlmann B. \& Solís A. 2001. The genus Onthophagus (Coleoptera: Scarabaeidae) in Costa Rica. Giornale Italiano di Entomologia 9: 159-261.

Krikken J. \& Huijbregts J. 2009. Onthophagus pilularius and its close relatives in Sundaland: a taxonomic reappraisal (Coleoptera: Scarabaeidae: Scarabaeinae). Deutsche Entomologische Zeitschrift 56 (1): 41-55. https://doi.org/10.1002/mmnd.200900004

Mannerheim C.G. 1829. Description de quarante nouvelles espèces de scarabéides du Brésil avec figures. Nouveaux mémoires de la Société impériale des naturalistes de Moscou 7 (1): 29-80.

Available from https://www.biodiversitylibrary.org/item/103533\#page/61/mode/1up [accessed 28 Mar. 2018].

Matthews E.G. 1972. A revision of the scarabaeine dung beetles of Australia. I. Tribe Onthophagini. Australian Journal of Zoology, Supplementary Series 9: 3-330. https://doi.org/10.1071/ajzs009 
Moctezuma V., Rossini M., Zunino M. \& Halffter G. 2016. A contribution to the knowledge of the mountain entomofauna of Mexico with a description of two new species of Onthophagus Latreille, 1802 (Coleoptera: Scarabaeidae: Scarabaeinae). Zookeys 572: 23-50.

https://doi.org/10.3897/zookeys.572.6763

Moczek A. 2011. Evolution and development: Onthophagus beetles and the evolutionary developmental genetics of innovation, allometry and plasticity. In: Simmons L.S. \& Ridsdill-Smith J.T. (eds) Ecology and Evolution of Dung Beetles: 126-151. Wiley-Blackwell, Oxford, UK.

https://doi.org/10.1002/9781444342000.ch7

Monteith G.B. \& Storey R.I. 2013. A review of the Onthophagus posticus-group (Coleoptera: Scarabaeidae: Scarabaeinae) of Australian dung beetles with five new species. Memoirs of the Queensland Museum 58: 55-72.

Morrone J.J. 2007. La vita fra lo spazio e il tempo. Il retaggio di Croizat e la nuova biogeografia. Medical Books, Palermo, Italy.

Morrone J.J. 2009. Evolutionary Biogeography. An Integrative Approach with Case Studies. Columbia University Press, New York.

Nichols E., Spector S., Louzada J., Larsen T., Amézquita S. \& Favila M.E. 2008. Ecological functions and ecosystem services provided by Scarabaeinae dung beetles. Biological Conservation 141 (6): 14611474. https://doi.org/10.1016/j.biocon.2008.04.011

Ortiz-Jaureguizar E. \& Cladera G.A. 2006. Paleoenvironmental evolution of southern South America during Cenozoic. Journal of Arid Environments 66: 498-532.

https://doi.org/10.1016/j.jaridenv.2006.01.007

Palestrini C. 1980. Aspetti filogenetici e biogeografici del popolamento australiano di Onthophagini (Coleoptera: Scarabaeoidea). M.Sc. Thesis, Università di Torino, Italy (unpublished).

Palestrini C. 1985. Problemi filogenetici e biogeografici del popolamento australiano di Onithophagini (Coleoptera: Scarabaeidae). In: Atti XIV Congresso Nazionale Italiano di Entomologia 14: 249-253. Accademia Nazionale Italiana di Entomologia, Palermo, Erice, Bagheria, Italy.

Papavero N. 1971. Essays on the History of Neotropical Dipterology, with Special Reference to Collectors (1750-1905). Vol. I. Museu de Zoologia, Universidade de São Paulo, São Paulo, Brazil. https://doi.org/10.5962/bhl.title.101715

Philips T.K. 2016. Phylogeny of the Oniticellini and Onthophagini dung beetles (Scarabaeidae: Scarabaeinae) from morphological evidence. Zookeys 579: 9-57.

https://doi.org/10.3897/zookeys.579.6183

Pulido-Herrera L.A. \& Zunino M. 2007. Catálogo preliminar de los Onthophagini de América (Coleoptera: Scarabaeinae). In: Zunino M. \& Melic A. (eds) Escarabajos, diversidad y conservación biológica. Ensayos en homenaje a Gonzalo Halffter: 93-129. Monografía Tercer Milenio 7. Sociedad Entomológica Aragonesa, Zaragoza, Spain.

QGIS Development Team 2017. QGIS Geographic Information System. (2.18.2). Open Source Geospatial Foundation Project. Available from http://qgis.org/en/site/ [accessed 22 Feb. 2018].

Rossini M., Vaz-de-Mello Z.F. \& Zunino M. 2018. A taxonomic revision of the New World Onthophagus Latreille, 1802 (Coleoptera: Scarabaeidae: Scarabaeinae) of the osculatii species-complex, with description of two new species from South America. Journal of Natural History 52 (9-10): 541-586. https://doi.org/10.1080/00222933.2018.1437230 
Ruggiero A., Lawton J.H. \& Blackburn T.M. 1998. The geographic ranges of mammalian species in South America: spatial patterns in environmental resistance and anisotropy. Journal of Biogeography 25: 1093-1103. https://doi.org/10.1046/j.1365-2699.1998.00253.x

Sager W.W., Schroeder W.W., Laswell J.S., Davis K.S., Rezak R. \& Gittings S.R. 1992. MississippiAlabama outer continental shelf topographic features formed during the Late Pleistocene - Holocene transgression. Geo-Marine Letters 12: 41-48. https://doi.org/10.1007/bf02092107

Schönherr C.J. 1808. Synonymia Insectorum, oder: Versuch einer Synonymie aller bisher bekannten Insecten; nach Fabricii Systema Eleutheratorum \& c. geordnet. Mit Berichtigungen und Anmerkungen, wie auch Beschreibungen neuer Arten und illuminirten kupfern. Erster Band. Eleutherata oder Käfer Zweither Theil. Spercheus - Cryptocephalus. Carl Friedr. Marquard, Stockholm. Available from https://www.biodiversitylibrary.org/item/133006\#page/1/mode/1up [accessed 28 Mar. 2018].

Schönherr C.J. 1817 Appendix ad C.J. Schönherr Synonymiam Insectorum Tom. I. Part. 3. Sistens descriptiones novarum specierum. E. Bruzelius, Stockholm. https://doi.org/10.5962/bhl.title.66107

Schoolmeesters P. 2016. Scarabs: World Scarabaeidae Database (v. Jan. 2016). In: Roskov Y., Abucay L., Orrell T., Nicolson D., Flann C., Bailly N., Kirk P., Bourgoin T., DeWalt R.E., Decock W. \& De Wever A. (eds) Species 2000 \& ITIS Catalogue of Life, 2016 Annual Checklist. Available from www.catalogueoflife.org/annual-checklist/2016 [accessed 22 Feb. 2018].

Sclater P.L. 1858. On the general geographic distribution of the members of the class Aves. Zoological Journal of the Linnean Society 2 (7): 130-145. https://doi.org/10.1111/j.1096-3642.1858.tb02549.x

Scotese C.R. 2004. Cenozoic and Mesozoic paleogeography: changing terrestrial biogeographic pathways. In: Lomolino M.V. \& Heaney L.R. (eds) Frontiers of Biogeography: New Directions in the Geography of Nature: 9-26. Sinauer Associates, Inc., Sunderland, Massachusetts, USA.

Smith A.Z. 1986. A History of the Hope Entomological Collections in the University Museum, Oxford, with Lists of Archives and Collections. Clarendon Press, Oxford, UK.

Snodgrass R.E. 1935. Principles of Insect Morphology. McGraw-Hill, New York/London.

Storey R.I. \& Weir T.A. 1990. New species of Onthophagus Latreille (Coleoptera: Scarabaeidae) from Australia. Invertebrate Taxonomy 3 (6): 783-815. https://doi.org/10.1071/it9890783

Tarasov S. \& Génier F. 2015. Innovative bayesian and parsimony phylogeny of dung beetles (Coleoptera: Scarabaeidae: Scarabaeinae) enhanced by ontology-based partitioning of morphological characters. PloS One 10 (3): e0116671. https://doi.org/10.1371/journal.pone.0116671

Tarasov S. \& Solodovnikov A.I. 2011. Phylogenetic analyses reveal reliable morphological markers to classify mega-diversity in Onthophagini dung beetles (Coleoptera: Scarabaeidae: Scarabaeinae). Cladistics 27 (5): 490-528. https://doi.org/10.1111/j.1096-0031.2011.00351.x

Torre-Bueno J.R de la. 1937. A Glossary of Entomology. Brooklyn Entomological Society, New York.

Varola P. 1980. Aspetti filogenetici e biogeografici del popolamento americano di Onthophagini (Coleoptera: Scarabaeoidea). M.Sc. thesis, Università di Torino, Italy (unpublished).

Zunino M. 1979. Gruppi artificiali e gruppi naturali negli Onthophagus (Coleoptera: Scarabaeoidea). Bollettino del Museo di Zoologia dell'Università di Torino 1: 1-18.

Zunino M. 1984. Sistematica generica dei Geotrupinae (Coleoptera: Scarabaeoidea: Geotrupidae), filogenesi della sottofamiglia e considerazioni biogeografiche. Bollettino del Museo di Zoologia dell'Università di Torino 2 (1): 9-162.

Zunino M. 2000. El concepto de área de distribución: algunas reflexiones teóricas. In: Martín-Piera F., Morrone J.J. \& Melic A. (eds) Hacia un proyecto CYTED para el inventario y estimación de la diversidad 
entomológica en Iberoamérica: PrIBES, 2000 1: 77-85. Sociedad Entomológica Aragonesa, Zaragoza, Spain.

Zunino M. 2003. Nuevos conceptos en la biogeografía histórica: implicaciones teóricas y metodológicas. In: Morrone J.J. \& Llorente Bousquet J. (eds) Una perspectiva latinoamericana de la biogeografía: 159-162. Universidad Nacional Autónoma de México, Mexico City.

Zunino M. 2014. About dung beetles (Coleoptera: Scarabaeoidea) genitalia: some remarks to a recent paper. Acta Zoológica Mexicana 30 (2): 437-441.

Zunino M. \& Halffter G. 1981. Descrizione di Onthophagus micropterus n.sp. (Coeloptera: Scarabaeidae), note sulla sua distribuzione geografica e sulla riduzione alare nel genere. Bollettino del Museo di Zoologia dell'Università di Torino 8: 95-110.

Zunino M. \& Halffter G. 1988. Análisis taxonómico, ecológico y biogeográfico de un grupo americano de Onthophagus. Museo Regionale di Scienze Naturale Torino, Monografia 9: 1-211.

Zunino M. \& Halffter G. 1997. Sobre Onthophagus Latreille, 1802 Americanos (Coleoptera: Scarabaeidae: Scarabaeinae). Elytron 11: 157-178.

Zunino M. \& Halffter G. 2007. The Association of Onthophagus Latreille, 1802 beetles (Coleoptera: Scarabaeinae) with Vertebrate burrows and caves. Elytron 21: 17-55.

Manuscript received: 10 May 2017

Manuscript accepted: 26 October 2017

Published on: 4 May 2018

Topic editor: Gavin Broad

Section editor: Max Barclay

Desk editor: Kristiaan Hoedemakers

Printed versions of all papers are also deposited in the libraries of the institutes that are members of the EJT consortium: Muséum national d'Histoire naturelle, Paris, France; Botanic Garden Meise, Belgium; Royal Museum for Central Africa, Tervuren, Belgium; Natural History Museum, London, United Kingdom; Royal Belgian Institute of Natural Sciences, Brussels, Belgium; Natural History Museum of Denmark, Copenhagen, Denmark; Naturalis Biodiversity Center, Leiden, the Netherlands; Museo Nacional de Ciencias Naturales-CSIC, Madrid, Spain; Real Jardín Botánico de Madrid CSIC, Spain; Zoological Research Museum Alexander Koenig, Bonn, Germany. 